\title{
EFFECT OF THE RAM ON DURATION OF OESTRUS IN THE EWE
}

\author{
S. D. PARSONS AND G. L. HUNTER \\ Department of Animal Science, University of Natal, \\ Pietermaritzburg, South Africa
}

(Received 6th May 1966)

\begin{abstract}
Summary. A series of experiments is reported in which the effect on the length of heat of varying degrees of association of the sexes was studied in Merino sheep. Length of heat in all ewes was determined by teasing with vasectomized rams at $4-\mathrm{hr}$ intervals. When present throughout oestrus, mating behaviour of rams and also of stilboestrol-treated ('masculinized') ewes, reduced heat length in experimental ewes by some 30 to $50 \%$. The sight, smell and sound of the rams were not sufficient to reduce the duration of oestrus. However, neither mounting nor intromission were necessary components of the male behaviour for the effect to be fully expressed. Oestrous periods synchronized by injections of progesterone were as effectively shortened by the continuous presence of the rams. The ewes were most sensitive to the effect of ram activity between 4 and $8 \mathrm{hr}$ after the beginning of oestrus, but oxytocin treatment during this time did not reduce oestrous duration.
\end{abstract}

\section{INTRODUCTION}

Considerable variation is to be found in the published estimates of the length of heat in sheep (Quinlan \& Maré, 1931; Grant, 1934; McKenzie \& Terrill, 1937; Hulet, Blackwell, Ercanbrack, Price \& Wilson, 1962; Hunter, 1962; Joubert, 1962; Joubert \& Louw, 1964; and others). Since overt characteristics accompanying oestrus are almost completely absent in the ewe, these reports have been based on observations of mating behaviour during continuous or, more commonly, intermittent periods of association of the sexes. The frequency of these so-called 'teasing' periods has varied from at least once in $2 \mathrm{hr}$ to once every $24 \mathrm{hr}$. It has been suggested that the association of the sexes may itself influence the duration of oestrus in the ewe. McKenzie \& Terrill (1937) reported that intermittent, sterile copulation 3, 12 and $24 \mathrm{hr}$ after the onset of oestrus tended to shorten its duration. Records at the Department of Animal Science (Hunter, 1964) indicated that the continuous association of ewes with active, breeding rams appears to shorten oestrous periods by some 6 to $8 \mathrm{hr}$. Preliminary observations were therefore made here during the 1963 to 1964 breeding season (Parsons, 1965) on the role of this factor on the duration of sexual receptivity of ewes when teased at intervals during oestrus. In a series 
of trials, the period during which teaser rams would mate with the test ewes was significantly reduced from a mean of about $22 \mathrm{hr}$, in groups entirely separated from rams between teasings, to between 11 and $16 \mathrm{hr}$ when sexually active rams remained with the ewes throughout oestrus. Various restrictions placed on these rams suggested that the period of receptivity by the ewe was not affected by the sound, sight and smell of the ram and, in particular, that intromission was not necessary to produce the effect. The hypothesis has, therefore, been adopted that the continuous presence of active rams during oestrus shortens the period during which ewes will accept service by the ram. In agreement with these observations, Zeltobrjuh \& Rak (1964) have recently reported that duration of oestrus is reduced by prolonged multiple mating of ewes at 2-hr intervals, as well as by association of the sexes without service during the same periods.

However, Pepelko \& Clegg (1964), in a brief abstract, have concluded that recently unmated oestrous ewes are greater sexual stimuli to sexually exhausted rams than oestrous ewes which have been recently mated. Thus, where rams are used to determine the duration of oestrus, such a reluctance to mate on the part of a fatigued teaser might erroneously be interpreted to mean that oestrus is over. Individual preferences on the part of either sex may be similarly misinterpreted. Although Lindsay \& Robinson (1961) found that ewes showed no apparent preference when allowed free choice of rams, Young (1941) recorded that towards the end of oestrus, ewes would not stand for service by certain rams and van Rensburg (1964) reported that ewes were reluctant to mate with 'strange' males. These and similar observations can give rise to alternative hypotheses which cannot be excluded as long as the use of teaser rams is essential in determining oestrus in the ewe.

This paper reports further investigations into the length of oestrus in the ewe, conducted during three periods in the 1964 to 1965 breeding season. The role of the ram in identifying oestrus and the problem of individual preferences were minimized by establishing a large pool of teasers from which sufficient virile rams were always available, and by the use of a system of grading oestrus, whereby emphasis was placed on the behaviour patterns of the ewes rather than those of the rams. The objects of the three experiments to be described were as follows: (1) to investigate heat lengths at three stages during the season in ewes subjected during oestrus to varying degrees of association with rams, and to determine what factor associated with the ram is responsible for the effect anticipated; (2) to determine the effects on heat length when rams are joined with ewes only during certain periods in oestrus; and (3) to determine the effects of rams on the length of progesterone-synchronized oestrus, and briefly to test the possibility that oxytocin release by the ewes may be involved in the mechanism of oestrus-shortening due to the presence of a ram.

\section{MATERIAL AND METHODS}

Over 500 ewes were available at the start of the season. About half were young ( 2 to 4 tooth) Merinos and the remainder were Döhne Merino type ewes of varying age. Between thirty and sixty vasectomized Dorper and German 
Merino rams were available at all times for teasing purposes. The sheep were housed in partly roofed pens. The normal daily ration of $2 \mathrm{lb}$ of milled lucerne hay/head and unlimited grass hay was varied occasionally to keep the ewes in medium to good condition. A salt and bonemeal lick and fresh water were always available.

The experimental treatments and recordings of heat lengths were carried out during three periods, 11 th to 27 th November, 4th to 23rd January and 1st to 19th February. Early in November the flock was divided in the pens into groups of about twenty-five ewes, each with one vasectomized ram. These rams were replaced frequently during the experimental periods by fresh rams. The onset of oestrus (time of first mating) in individual ewes was determined throughout each of the three periods by constant observation for mating behaviour. Immediately a ewe was first mated, she was removed to a treatment pen and the lengths of oestrus of the ewes in all treatment groups was determined by teasing at 4 -hr intervals. In order to reduce the possibility of under-estimating heat

TABLE 1

GRADING SYSTEM FOR OESTROUS BEHAVIOUR

\begin{tabular}{c|c}
\hline Grade & Description of ewe behaviour \\
\cline { 2 - 2 } 1 & Ewe moves towards ram, or ram locates and mounts ewe soon after introduction to the pen; \\
& ewe stands firm when mounted \\
2 & Ram teases ewe for a few minutes before mounting; little movement by ewe when mounted \\
3 & Ewe moves a few steps when ram mounts, but ram is able to accomplish service \\
4 & Ewe runs when ram mounts and ram is unable to copulate \\
5 & Ewe moves away as ram attempts to mount, so mounting does not occur \\
6 & Ewe darts away from ram when he commences teasing or attempts to mount; however, \\
7 & ram shows considerable interest in ewe \\
\hline
\end{tabular}

For purposes of measuring length of oestrus, only ewes graded 1, 2 or 3 were regarded as on heat.

length through the reluctance of teaser rams to mount recently mated ewes (Pepelko \& Clegg, 1964), the criterion used in all the experiments to determine the end of oestrus was based on the ewes' reactions to rams exhibiting high libido. For this purpose, intensity of oestrus was graded at each teasing period (see Table 1) and when a ewe appeared to be going off heat she was teased with at least three highly active rams. In order to keep the effect of teasing on oestrous duration to a minimum, the rams were permitted to mount a ewe only once at each teasing. Periods of non-receptivity in the oestrous ewe have been reported (Hunter, 1964). To allow detection of such 'breaks' in heat, when ewes no longer permitted copulation at the regular 4-hourly teasing they were again run with vasectomized rams and kept under continuous observation. Any ewe that stood for service at this stage was immediately returned to the appropriate treatment pen. The duration of each oestrus was calculated as the interval between first mating and the last teasing graded 1, 2 or 3 .

Starting on 11 th November, each block of fourteen ewes of one breed that came on heat consecutively, was randomly allocated to seven treatment groups, 
two to each group. This ensured that ewes of each breed that came on heat within a short interval of each other were allocated equally to all treatments. The first period of heat length observations continued until 27th November, when at least forty-two ewes had been allocated to each treatment. During periods 2 (4th to 23rd January) and 3 (1st to 19th February) the numbers of ewes in each treatment varied because some of the ewes allocated to the treatment groups during November did not exhibit oestrus during the later periods. 'Students' $t$-test was used throughout to determine the significance of the differences between treatment means.

\section{Experiment 1}

This experiment (Tables 2 and 3) was designed to investigate whether association of the sexes during oestrus reduces heat length, to determine what 'factor' associated with the ram has such an effect and to assess the variation of this effect through the season. During the first period (11th to 27th November), six groups of ewes were subjected to varying degrees of association with rams, as follows: Treatment 1 , teased at 4 -hr intervals only; Treatment 2 , a ram was penned alongside the group so that he was only heard and smelled by the ewes; Treatment 3, a ram was penned alongside so that he was seen, heard and smelled; Treatment 4, a ram was run with the ewes in a pen covered a few inches above their shoulder height by wire netting on a wooden frame, so that the normal precopulatory mating behaviour was permitted, but mounting by the ram was prohibited; Treatment 5 , these ewes were run with a ram that was able to mount, but was prevented from copulating by means of a canvas apron; and Treatment 6, an unrestricted ram remained with these ewes. Ewes in a seventh treatment group were run throughout oestrus with stilboestrol-treated 'masculinized' ewes (Lishman \& Hunter, 1965). These ewes exhibited typical male-like mating behaviour. Although no information was available on the effect of this masculinization on the scent of the stilboestrol-treated ewe, this appeared to offer a good opportunity to attempt the elimination of the effects of the sight and perhaps the smell of the ram, as well as the effect of intromission, while retaining the effect of male-like mating behaviour alone.

Groups 1, 4 and 6 received the same treatments in November, January and February. In February an additional group of ewes, not previously used for experimental purposes (Group 8), was run with a ram not able to mount, a duplicate of Treatment 4. During November, the unrestricted ram in Group 6 was changed every $6 \mathrm{hr}$, while the ram in Group 4 that was unable to mount was changed only every $24 \mathrm{hr}$ on the assumption that, since he was not mating, his libido would remain high for a longer period. However, during January and February the rams in Groups 4, 6 and 8 were changed every $6 \mathrm{hr}$.

\section{Experiment 2}

This experiment (Table 4) was designed to determine the effects of the ram on heat length when associated with the ewes only at certain stages of oestrus. In January and February, the ewes from Groups 2 and 7 in Experiment 1 were allocated at random to new treatment groups as they came on heat. In January, the new treatments consisted of continuously associating the sexes from either 
the 4 th, 8th or 12th hr after the start of oestrus, or for the first $4 \mathrm{hr}$ of oestrus only. In February, these ewes were continuously associated with unrestricted rams for only the first, second or third $4 \mathrm{hr}$ of oestrus. In both months, the mean heat lengths recorded for these treatments were compared with those obtained in Experiment 1 during the same periods for ewes teased only at 4-hr intervals (Group 1) and for ewes continuously associated with an unrestricted ram (Group $6)$.

\section{Experiment 3}

It is well known that lactating females eject milk from the mammary glands during coitus. VanDemark \& Hays (1952) showed that oxytocin is secreted during mating and is responsible for a rise in intramammary pressure and for uterine contractions in the cow. These observations have been interpreted to mean that coitus induces nervous impulses that reach the neurohypophysis through the hypothalamus, activating the release of oxytocin. It therefore seems possible that the action of the ram in reducing the duration of oestrus may be due to neurohumoral action involving oxytocin.

In an attempt to establish whether oxytocin might be involved in reducing heat length in the ewe, it was planned to inject oxytocin intravenously between the 4th and 8th hr of oestrus, the period when the ram's effect on heat length appears to be greatest (Experiment 2). With a view to simplifying the experimental procedure, oestrus in twenty-four ewes was synchronized during January by twenty-one daily injections of $10 \mathrm{mg}$ progesterone in oil. To determine whether progesterone treatment affected heat length and the ram's ability to reduce it, twelve of these ewes were run with a vasectomized ram throughout the first synchronized oestrus and the length of heat of all ewes was determined by teasing at 4-hr intervals. During the second oestrus in February, the ewes were re-allocated to two groups, one of which was injected with oxytocin and, as before, heat length was determined for all ewes by 4-hourly teasing.

The highest dose of oxytocin recommended for obstetrical use in the ewe is 50 U.S.P. units (Barker \& Wiggins, 1964). Braden \& Moule (1964) injected 20 to 30 B.P. units in sheep, although for different purposes. Since it was impossible to determine the total amount of oxytocin secreted by a ewe during unrestricted mating, an arbitrary level of 30 oxytocic (B.P.) units ('Pitocin'Parke, Davis \& Co.) was injected/ewe during oestrus. Thus 4, 6 and $8 \mathrm{hr}$ after the beginning of oestrus the twelve ewes received intravenous injections of 10 oxytocic units.

Once again, the mean heat lengths recorded during January and February for Groups 1 and 6 (Experiment 1), though unsynchronized, may be compared, with those of this experiment (Tables 5 and 6).

\section{RESULTS}

\section{Experiment 1}

The mean heat lengths presented in Table 2 show no significant effect of the sight, smell and sound of the ram and that a ram which mounts without copulating (Group 5) is as effective as an unrestricted ram in reducing heat 
length. Greater reduction of heat length might have been achieved by the teaser ewes if more than the three which were active during the period of the experiment had been available. However, this group has provided further evidence that neither intromission nor the sight of the ram during oestrus are essential for oestrus to be shortened.

TABLE 2

MEAN LENGTHS OF HEAT DURING NOVEMBER FOR TREATMENT GROUPS IN EXPERIMENT 1

\begin{tabular}{c|l|c|c}
\hline \multicolumn{1}{|c|}{ Treatment } & $\begin{array}{c}\text { No. } \\
\text { of } \\
\text { ewes }\end{array}$ & $\begin{array}{c}\text { Mean heat length } \\
\text { and standard } \\
\text { error }(h r)\end{array}$ \\
\hline No. & Description & 42 & $21 \cdot 9 \pm 1 \cdot 5^{a}$ \\
1 & Teased at 4-hr intervals & $39 *$ & $23 \cdot 8 \pm 1 \cdot 2^{a}$ \\
2 & Ram heard and smelled & 42 & $21 \cdot 1 \pm 1 \cdot 7^{a}$ \\
3 & Ram seen, heard and smelled & 43 & $15 \cdot 4 \pm 1 \cdot 0^{b}$ \\
4 & Ram unable to mount & 42 & $10 \cdot 8 \pm 1 \cdot 0^{c}$ \\
6 & Aproned ram & 42 & $10 \cdot 2 \pm 1 \cdot 1^{c}$ \\
7 & Unrestricted ram & 44 & $15 \cdot 2 \pm 1 \cdot 3^{b}$ \\
\hline
\end{tabular}

$a, b, c$ Mean heat lengths having the same superscripts are not significantly different from each other.

* Three records of heat length were found to be incomplete after the experiment ended.

It is apparent in Table 3 that heat lengths increased somewhat as the season progressed. In November, although mating behaviour without mounting did not reduce heat length by as much as the presence of an unrestricted ram, this can probably be attributed to the ram in Group 4 in November being less

TABLE 3

MEAN LENGTHS OF HEAT DURING THREE PERIODS OF THE BREEDING SEASON IN EXPERIMENT 1

\begin{tabular}{|c|c|c|c|c|c|c|c|}
\hline \multicolumn{2}{|r|}{ Treatment } & \multicolumn{2}{|r|}{ November } & \multicolumn{2}{|r|}{ January } & \multicolumn{2}{|r|}{ February } \\
\hline No. & Description & $\begin{array}{l}\text { No. } \\
\text { of } \\
\text { ewes }\end{array}$ & $\begin{array}{c}\text { Mean heat length } \\
\text { and standard } \\
\text { error }(h r)\end{array}$ & $\begin{array}{l}\text { No. } \\
\text { of } \\
\text { ewes }\end{array}$ & $\begin{array}{c}\text { Mean heat length } \\
\text { and standard } \\
\text { error }(h r)\end{array}$ & $\begin{array}{l}\text { No. } \\
\text { of } \\
\text { ewes }\end{array}$ & $\begin{array}{c}\text { Mean heat length } \\
\text { and standard } \\
\text { error }(h r)\end{array}$ \\
\hline $\begin{array}{l}1 \\
4 \\
6 \\
8\end{array}$ & $\begin{array}{l}\text { Teased at 4-hr } \\
\text { intervals } \\
\text { Ram unable to mount } \\
\text { Unrestricted ram } \\
\text { Ram unable to mount }\end{array}$ & $\begin{array}{l}42 \\
43 \\
42 \\
-\end{array}$ & $\begin{array}{l}21 \cdot 9 \pm 1 \cdot 5^{a} \\
15 \cdot 4 \pm 1 \cdot 0^{c} \\
10 \cdot 2 \pm 1 \cdot 1^{d} \\
=\end{array}$ & $\begin{array}{l}34 \\
42 \\
34 \\
-\end{array}$ & $\begin{array}{c}23 \cdot 4 \pm 1 \cdot 6^{a, b} \\
14 \cdot 4 \pm 1 \cdot 1^{c} \\
14 \cdot 3 \pm 1 \cdot 0^{c, d} \\
-\end{array}$ & $\begin{array}{l}33 \\
39 \\
32 \\
29\end{array}$ & $\begin{array}{l}27 \cdot 6 \pm 1 \cdot 4^{b} \\
16 \cdot 2 \pm 1 \cdot 3^{c} \\
15 \cdot 9 \pm 1 \cdot 2^{c} \\
15 \cdot 1 \pm 1 \cdot 1^{c}\end{array}$ \\
\hline
\end{tabular}

$a, b, c, d$ Mean heat lengths with any part of the superscript the same are not significantly different from each other.

active than when changed more frequently in January and February (Table 3). In addition, the relatively shorter heat lengths recorded in Group 4 in January and February cannot be attributed to previous association with the ram, because during February there was no significant difference in heat length between Groups 4 and 8. 
Heat lengths for individual ewes not associated continuously with rams during oestrus were relatively constant from one heat to the next. This is suggested by a high correlation coefficient $(0.87)$ between the duration of oestrus in January and February for Group 1, though over a longer period (November to January) a lower correlation was found $(0 \cdot 67)$. The heat lengths of individual ewes were not consistently reduced by the ram during different oestrous periods. This is indicated for Groups 4 and 6 by low correlation coefficients between heat lengths in November and January of 0.38 and 0.29 and between January and February of 0.36 and 0.29 respectively.

\section{Experiment 2}

From the results of the January series (Table 4) it is apparent that, if the continuous presence of the ram began at any time up to $12 \mathrm{hr}$ after the beginning

TABLE 4

TREATMENTS AND MEAN LENGTHS OF HEAT RECORDED IN EXPERIMENT 2

\begin{tabular}{|c|c|c|c|c|}
\hline \multirow{2}{*}{$\begin{array}{l}\text { Group } \\
\text { No. }\end{array}$} & \multicolumn{2}{|c|}{ Hours of oestrus } & \multirow{2}{*}{$\begin{array}{c}\text { No. } \\
\text { of } \\
\text { ewes }\end{array}$} & \multirow{2}{*}{$\begin{array}{l}\text { Mean heat length } \\
\text { and standard error } \\
(\mathrm{hr})\end{array}$} \\
\hline & $\begin{array}{lll}0 & 4 & 8\end{array}$ & $12 \ldots$ End & & \\
\hline $\begin{array}{c}\text { anuary } \\
1 \\
6 \\
\mathrm{~J} 1 \\
\mathrm{~J} 2 \\
\mathrm{~J} 3 \\
\mathrm{~J} 4\end{array}$ & - & & $\begin{array}{l}34 \\
34 \\
17 \\
16 \\
17 \\
17\end{array}$ & $\begin{array}{l}23 \cdot 4 \pm 1 \cdot 6^{a} \\
14 \cdot 3 \pm 1 \cdot 0^{b, c} \\
11 \cdot 4 \pm 1 \cdot 1^{b} \\
16 \cdot 3 \pm 0 \cdot 9^{c} \\
17 \cdot 5 \pm 0 \cdot 8^{c} \\
16 \cdot 3 \pm 1 \cdot 8^{b, c}\end{array}$ \\
\hline $\begin{array}{c}\text { February } \\
1 \\
6 \\
\text { F1 } \\
\text { F2 } \\
\text { F3 }\end{array}$ & $\overline{-}$ & & $\begin{array}{l}33 \\
32 \\
23 \\
26 \\
25\end{array}$ & $\begin{array}{l}27 \cdot 6 \pm 1 \cdot 4^{a} \\
15 \cdot 9 \pm 1 \cdot 2^{b} \\
21 \cdot 1 \pm 2 \cdot 0^{c} \\
18 \cdot 6 \pm 19^{b, c} \\
19 \cdot 7 \pm 1 \cdot 9^{b, c}\end{array}$ \\
\hline
\end{tabular}

Period during oestrus when unrestricted ram was present is indicated by a continuous line.

$a, b, c$ Within each month, mean heat lengths with any part of the superscript the same are not significantly different from each other.

of oestrus, heat length was reduced. However, the ram had the greatest effect if introduced $4 \mathrm{hr}$ after the onset of oestrus. From the February series it can be seen that rams present for 4-hr periods reduced heat length when introduced at the 4 th or 8 th hr of oestrus, but had only a partial effect in the first $4 \mathrm{hr}$.

\section{Experiment 3}

Progesterone synchronization had no effect on oestrus duration or its reduction by the ram (Table 5). Oxytocin treatment during oestrus did not affect heat length or the length of the subsequent oestrous cycles (Table 6). No explanation can be offered for the relatively short mean heat length of Group C2. 


\section{DISCUSSION}

In the first experiment reported here, as well as in the preliminary trials conducted during the previous breeding season, the smell, sight and typical vocalization of the sexually active ram had no apparent effect on heat length. Zeltobrjuh \& Rak (1964) reported that rams in adjoining pens reduced heat lengths slightly. In their paper (a translation of which has been studied) no

TABLE 5

RESULTS OF EXPERIMENT 3 DURING JANUARY, SHOWING MEAN LENGTHS OF HEAT IN PROGESTERONE-SYNCHRONIZED AND IN NON-SYNCHRONIZED GROUPS

\begin{tabular}{|c|c|c|c|}
\hline $\begin{array}{l}\text { Group } \\
\text { No. }\end{array}$ & Description of treatment & $\begin{array}{l}\text { No. } \\
\text { of } \\
\text { ewes }\end{array}$ & $\begin{array}{c}\text { Mean heat length } \\
\text { and standard error } \\
(\text { hr })\end{array}$ \\
\hline $\begin{array}{l}\text { Synchron } \\
\text { C1 } \\
\text { T1 }\end{array}$ & $\begin{array}{l}\text { Teased at 4-hr intervals } \\
\text { Run with unrestricted ram }\end{array}$ & $\begin{array}{l}12 \\
12\end{array}$ & $\begin{array}{l}22 \cdot 1 \pm 1 \cdot 3^{a} \\
10 \cdot 7 \pm 1.0^{b}\end{array}$ \\
\hline $\begin{array}{l}\text { Non-sync } \\
1 \\
6\end{array}$ & $\begin{array}{l}\text { Teased at 4-hr intervals } \\
\text { Run with unrestricted ram }\end{array}$ & $\begin{array}{l}34 \\
34\end{array}$ & $\begin{array}{l}23 \cdot 4 \pm 1 \cdot 6^{a} \\
14 \cdot 3 \pm 1 \cdot 0^{b}\end{array}$ \\
\hline
\end{tabular}

$a, b$ Mean heat lengths having the same superscripts are not significantly different from each other.

indication is given of the use of statistical tests of differences between treatment means and it is possible that their conclusions would not be supported by such tests. The need to use rams to determine heat length in ewes is a more serious obstacle in the study of such 'partial' effects than it is in establishing the gross effects on heat length of the continuous presence of the ram.

\section{TABLE 6}

MEAN OESTRUS AND SUBSEQUENT OESTROUS GYGLE LENGTHS IN GONTROL AND OXYTOCIN-TREATED EWES IN EXPERIMENT 3, AND FEBRUARY HEAT LENGTHS IN COMPARABLE NON-SYNCHRONIZED EWES

\begin{tabular}{|c|c|c|c|c|}
\hline $\begin{array}{c}\text { Group } \\
\text { No. }\end{array}$ & Description of treatment & $\begin{array}{l}\text { No. } \\
\text { of } \\
\text { ewes }\end{array}$ & $\begin{array}{c}\text { Mean heat length } \\
\text { and standard error } \\
\qquad(h r)\end{array}$ & $\begin{array}{c}\text { Mean cycle } \\
\text { length } \\
\text { (days) }\end{array}$ \\
\hline $\begin{array}{r}\mathrm{C} 2 \\
\mathrm{~T} 2 \\
1 \\
6\end{array}$ & $\begin{array}{l}\text { Teased at 4-hr intervals } \\
\text { Oxytocin treated during oestrus } \\
\text { Teased at 4-hr intervals } \\
\text { Run with unrestricted ram }\end{array}$ & $\begin{array}{l}12 \\
12 \\
33 \\
32\end{array}$ & $\begin{array}{l}19 \cdot 7 \pm 1 \cdot 3^{a} \\
28 \cdot 1 \pm 1 \cdot 4^{b} \\
27 \cdot 6 \pm 1 \cdot 4^{b} \\
15 \cdot 9 \pm 1 \cdot 2^{a}\end{array}$ & $\begin{array}{l}17 \cdot 0 \\
16 \cdot 7 \\
- \\
-\end{array}$ \\
\hline
\end{tabular}

$a, b$ Mean heat length having the same superscripts are not significantly different from each other.

McKenzie \& Terrill (1937) attributed reduced heat length to copulation. The effects of mounting and intromission without the concomitant behavioural patterns of the ram were not tested in these experiments. However, the addition of these actions did not decrease heat lengths more than did the presence of rams that were unable to mount. Thus, the precopulatory mating behaviour of the ram appears to be sufficient stimulus to reduce heat length. 
The failure to demonstrate that oxytocin injections during oestrus can shorten it, does not exclude the possibility of effectiveness of other dosage levels and times of treatment with this hormone. The possibilities that the mechanism of the effect of the ram on heat length in the ewe involves the ovarian hormones, or a neural mechanism not involving hormones, must also be considered. The complex patterns of behaviour which emerge during oestrus are innate and mediated through the central nervous system (Eayrs \& Glass, 1962). In the ewe, oestrous behaviour is attributed to the direct action of oestrogen on the central nervous system, with pre-ovulatory progesterone playing an important synergistic role (Robinson, 1954). However, the amount of oestrogen secreted by the ovaries does not appear to affect heat length (Young, 1961; van Rensburg, 1964). Therefore, since the gonadotrophic hormones may be regarded as having no influence on sexual behaviour other than that mediated through their control of ovarian secretions (Eayrs \& Glass, 1962), it is suggested that, if oxytocin release is not responsible, the exteroceptive stimuli emanating from the ram may act directly on the nervous system of the ewe, causing earlier termination of oestrus.

An experiment to determine the effect of the continuous presence of rams on the time of ovulation in the ewe is reported separately (Parsons, Hunter \& Rayner, 1967).

\section{ACKINOWLEDGMENTS}

The Merino ewes used in these experiments were donated by members of the Natal and East Griqualand Wool Growers' Association; other animals and facilities were provided by the South African Department of Agricultural Technical Services. Dr G. P. Bishop performed the numerous vasectomies. The staff of the Ukulinga Experiment Station cared for the experimental animals and Miss S. Withey, Mr A. W. Lishman, Mr M. J. Runciman and Mr F. Venter assisted in collecting the data. One of us (S.D.P.) conducted these experiments during the tenure of the William Adam Memorial Bursary awarded by Messrs Stockowners Co-operative Company, Pietermaritzburg. The authors' appreciation is expressed to all of the above people.

\section{REFERENCES}

BARKER, H. B. \& Wiggins, E. L. (1964) Occurrence of post-partum estrus in fall-lambing ewes. $\mathcal{F}$. Anim. Sci. 23, 967.

Braden, A. W. H. \& Moule, G. R. (1964) Effects of stress on ovarian morphology and oestrous cycles in ewes. Aust. 7. agric. Res. $15,937$.

EAYRs, J. T. \& Glass, A. (1962) The ovary and behaviour. In: The Ovary, Vol. II, chap. 20. Ed. S. Zuckerman. Academic Press, London.

Grant, R. (1934) Studies on the physiology of reproduction in the ewe. I. The symptoms, periodicity and duration of oestrus. Trans. R. Soc. Edinb. 58, 1.

Hulet, C. V., Blackwell, R. L., Ercanbrack, S. K., Price, D. A. \& Wilson, L. O. (1962) Mating behaviour of the ewe. F. Anim. Sci. 21, 870.

Hunter, G. L. (1962) Observations on oestrus in Merinos. Proc. S. Afr. Soc. Anim. Prod. 1, 67.

Hunter, G. L. (1964) The effects of season and mating on oestrus and fertility in the ewe. Proc. S. Afr. Soc. Anim. Prod. 3, 196.

Joubert, D. M. (1962) Sex behaviour of the purebred and crossbred Merino and Blackhead Persian ewes. F. Reprod. Fert. 3, 41. 
Joubert, D. M. \& Louw, D. F. J. (1964) Observations on the sex behaviour of Dorper and Döhne Merino ewes. Proc. S. Afr. Soc. Anim. Prod. 3, 139.

Lindsay, D. R. \& Robinson, T. J. (1961) Oestrus-inducing activity of testosterone in the ewe. Nature, Lond. 192, 761.

Lishman, A. W. \& Hunter, G. L. (1965) Induction of masculine sexual behaviour in the ewe using stilboestrol and P.M.S. Proc. S. Afr. Soc. Anim. Prod. 4, 142.

MaKenzie, F. F. \& Terrill, C. E. (1937) Estrus, ovulation and related phenomena in the ewe. Univ. Mo. agric. Res. Bull. 264.

Parsons, S. D. (1965) The influence of the ram on oestrus and ovulation in the ewe. Thesis, University of Natal.

Parsons, S. D., Hunter, G. L. \& Rayner, A. A. (1967) Use of probit analysis in a study of the effect of the ram on time of ovulation in the ewe. F. Reprod. Fert. 14, 71.

Pepelko, W. E. \& Clegg, M. J. (1964) Factors affecting recovery of sex drive in the sexually exhausted male sheep, Ovis aries. Fedn Proc. Fedn Am. Socs exp. Biol. 23, 362.

Quinlan, J. \& MARÉ, G. S. (1931) The physiological changes in the ovary of the Merino sheep in South Africa and their practical application in breeding. 17th Rep. Dir. Vet. Serv., Onderstepoort, Un. S. Afr. p. 663.

Robinson, T. J. (1954) The necessity for progesterone with estrogen for the induction of recurrent estrus in the ovariectomised ewe. Endocrinology, 55, 403.

VanDemark, N. L. \& Hays, R. L. (1952) Uterine motility responses to mating. Am. F. Physiol. 170, 518.

vAN RENSBURG, S. J. (1964) Ovum production: Action of various gonadotrophins in sheep and goats. Onderstepoort 7. vet. Res. 31, 96.

Young, W. C. (1941) Observations and experiments on mating behaviour in female mammals. Q. Rev. Biol. 16, 135, 311.

Younc, W. C. (1961) The mammalian ovary. In: Sex and Internal Secretions, Vol. I, chap. 7. Ed. W. C. Young. Williams \& Williams, Baltimore.

Zeltobrjuh, N. A. \& Rak, L. P. (1964) Biological stimulation of the reproductive functions of the ewe. Ovcevodstvo, 10 (8), 8. (Anim. Breed. Abstr. 33, 448, 1965). 